ORIGINAL ARTICLE

\title{
Clearing the cervical spine of paediatric trauma patients
}

\author{
S E Slack, M J Clancy
}

Emerg Med J 2004;21:189-193. doi: 10.1136/emj.2003.012310

See end of article for authors' affiliations .....................

Correspondence to: Mrs S E Slack.

1 Andrewes Close, Bishop's Waltham, Hampshire SO32 1GY, UK; suslack@doctors.org.uk

Accepted for publication 30 October 2003

\begin{abstract}
Objectives: To review the evidence available for clearance of the cervical spine in children under 16 years of age after trauma, and to provide guidance to enable this to be practised safely.

Methods: A comprehensive literature review was carried out, and combined with a review of standard texts and liaison with experts.

Results: 241 papers were identified, of which 71 papers were thought possibly relevant. These were obtained and appraised. Children in whom there is concern about possible cervical spine injury may be divided into three groups. Alert, asymptomatic children with a normal examination may be clinically cleared without need for radiology. Children with cervical spine symptoms or signs require plain radiology in the first instance. Those areas that are poorly visualised or suspicious should be discussed with a paediatric radiologist and are likely to undergo computed tomography. Children with impaired conscious level require careful evaluation. Plain radiology, if normal, can be usefully complemented by early magnetic resonance imaging to exclude ligamentous and spinal cord damage.

Conclusions: There is limited evidence to guide clinicians on how to clear the paediatric cervical spine. The approach suggested is similar to adult recommendations made elsewhere, and the differences are highlighted.
\end{abstract}

$\mathrm{E}$ mergency physicians are the first to assess and manage traumatised patients, including children. This paper (c-spine) in children less than 16 years of age.

The c-spine is cleared when the clinician is satisfied, after appropriate history, examination, and investigation, that the risk of an important injury being present is negligible. "Important" injuries include vertebral bony injuries, ligamentous injuries, and spinal cord injuries. Similar reviews for adults have been written and algorithms produced. ${ }^{1-6}$ The evaluation of children with potential cervical spine injuries, while sharing some of the problems of adult patients, has some important differences. (See table 1)

\section{DISTRIBUTION}

C-spine injuries are rare in the young and they tend to have more upper cervical injuries when compared with adults. ${ }^{7-14}$ These differences can be explained by the anatomy of the paediatric c-spine which becomes adult-like at about 8 years of age. The infant has a comparatively large and heavy head resulting in a different inertial force, ligaments and joint capsules are more lax, facets are more horizontal, and the vertebral bodies are wedge shaped..$^{15}$ These factors predispose the c-spine to greater mobility, with high torques and shear forces being applied to $\mathrm{C} 1$ and $\mathrm{C} 2$ with increased risk of injury at those levels. ${ }^{711} 16$

\section{MECHANISM OF INJURY}

Road traffic accidents (RTAs) (particularly pedestrians hit by cars, or passengers involved in high speed vehicular accidents), sport/playground injuries, and falls from a height are the commonest causes. ${ }^{817}{ }^{18}$ Many of the high cervical injuries result in death at the scene, so there is a relative under-representation of these injuries in hospital series. ${ }^{8} 19$

The possibility of a c-spine injury, coupled with the consequences of missing such an injury, are serious. The American College of Surgeons, through the Advanced Trauma Life Support (ATLS) course, advise that all unconscious patients with an injury above the clavicles and all patients involved in high speed vehicular accidents should be assumed to have a spinal injury. ${ }^{20}$

\section{RADIOLOGY}

Interpretation of paediatric c-spine radiographs is difficult, especially for those who see comparatively few cases (see fig 1). There are various normal variants, including pseudosubluxation (occurs in $24 \%$ of children $<8$ years at $\mathrm{C} 2 / 3$ and $14 \%$ at $\mathrm{C} 3 / 4)^{23}$ (fig 2), absence of lordosis, epiphyseal variations, unfused synchondroses, and incomplete ossification. ${ }^{9162122}$ There is an understandable tendency to conclude that some of these normal variants represent actual injury. The advice of a paediatric radiologist can be invaluable in distinguishing the two.

\section{SPINAL CORD INJURY WITHOUT RADIOLOGICAL ABNORMALITY (SCIWORA)}

SCIWORA is a real phenomenon, more common in children than adults. ${ }^{17}{ }^{23-25}$ It is defined as objective signs of myelopathy as a result of trauma with no evidence of fracture or ligamentous instability on plain spine radiographs and tomography. ${ }^{26}$ Reported incidence varies widely, but is likely to be $10 \%-20 \%$ of all paediatric spinal cord injuries. ${ }^{27}$ There can be a delayed onset to the "objective signs of myelopathy" (of up to four days), so neurologically normal children with a history of transient neurological symptoms should also be taken seriously. The mainstay of treatment is immobilisation, and MRI can provide prognostic information.

This review attempts to find the best evidence available to help clinicians involved in the difficult task of clearing the paediatric c-spine, highlighting differences with adults. It does not include management of specific spinal injuries.

\section{METHOD}

Literature search

A comprehensive literature search was carried out using the following: 
Table 1 Differences in c-spine injuries and clearance in adults and children

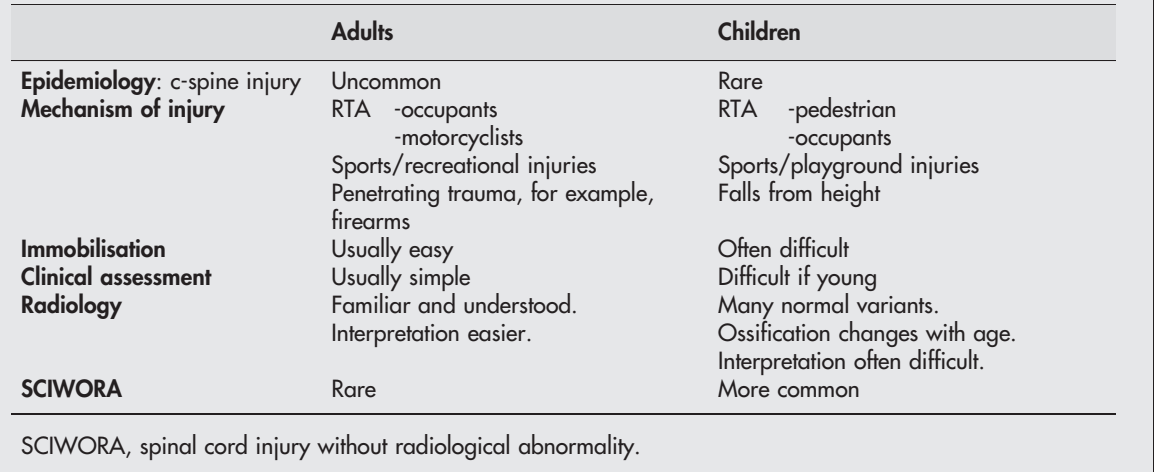

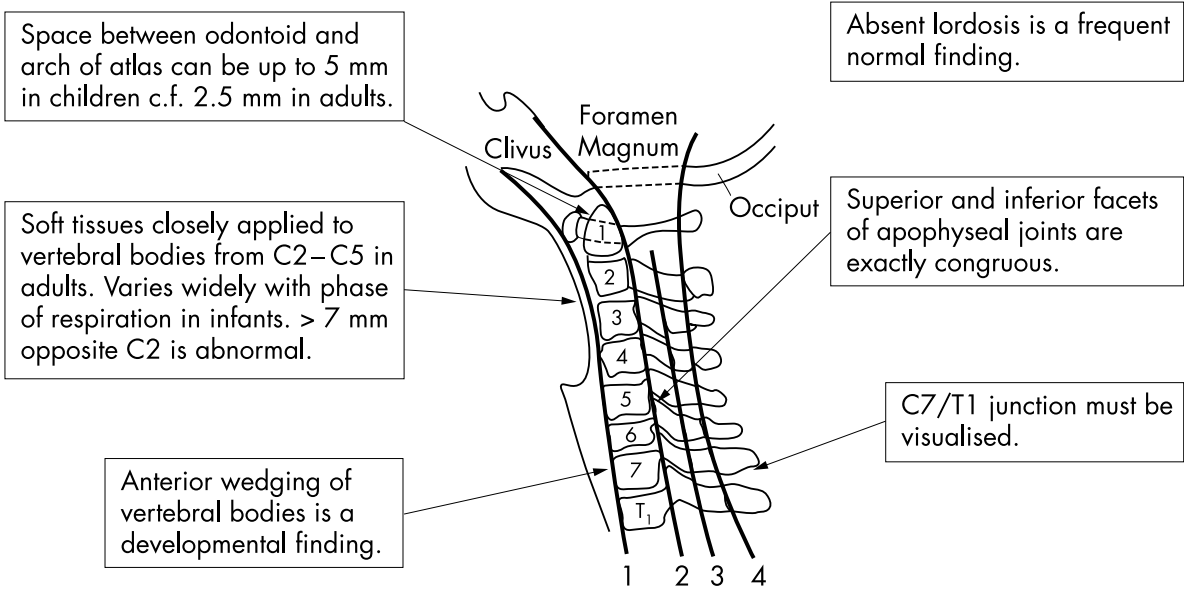

Figure 1 Interpretation of lateral c-spine radiographs in children $\leqslant 8$ years of age (Based on figure from APLS Manual, 3rd edn).

The four lines shown in the figure are:

1. Anterior vertebral line.

2. Posterior vertebral line (anterior wall of the spinal canal).

3. Facet line.

4. Spino-laminar line (posterior wall of spinal canal).

All 4 lines should be smooth with no steps or angulation. The spinolaminar line remains smooth even in the presence of pseudosubluxation.

(a) Medline 1966- 10/2001, EMBASE 1988-10/2001, and CINAHL 1/82-5/2001.

Terms used (exp Cervical Vertebrae OR cervical spine.mp) AND (Child OR exp Pediatrics) AND (exp X-Rays OR Xray.mp OR exp Radiography OR Computerised Tomography (CT) OR Magnetic Resonance Imaging (MRI)) AND (exp Wounds and Injuries) OR Clearance. LIMIT to human and English language.

(b) The Cochrane Library

(c) A bibliographical search of those papers identified by the above.

Those papers identified were appraised in the manner recommended by Sackett $e t a^{28}$ as for a diagnostic test.

\section{Review of standard texts}

Standard texts in common use in the emergency department or radiology department were consulted. These included the manuals for Advanced Trauma Life Support, ${ }^{20}$ Advanced Paediatric Life Support, ${ }^{23}$ Emergency Medicine, ${ }^{29}$ Imaging Children, ${ }^{9}$ Caffey's Pediatric X-ray Diagnosis: an Integrated Approach, ${ }^{30}$ The Clinical Practice of Emergency Medicine, ${ }^{16}$ and Atlas of Normal Roentgen Variants That May Simulate Disease. ${ }^{31}$
A

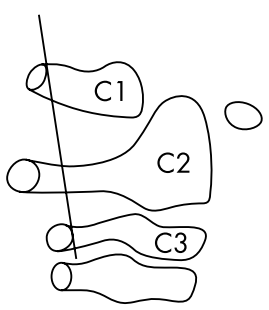

B

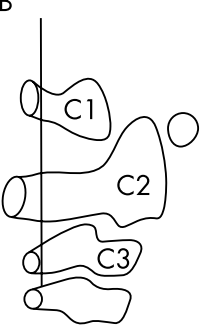

C

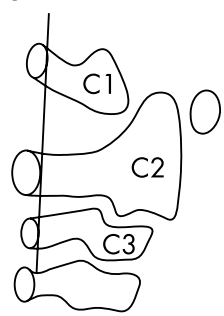

Figure 2 In those children demonstrating subluxation of C2 on C3 the posterior cervical line (PCL) of Swischuk can be drawn. This connects the anterior aspect of the spinous processes of $\mathrm{Cl}$ and $\mathrm{C} 3$. If the anterior aspect of the spinous process of $C 2$ misses this line by $\geqslant 2 \mathrm{~mm}$ true subluxation of hangman's fracture must be considered. This line is only applicable to those demonstrating subluxation. The distance is frequently $2 \mathrm{~mm}$ or more if no subluxation is apparent. (A) No subluxation.

Therefore, $\mathrm{PCL}$ cannot be applied. Anterior aspect of spinous process of C2 commonly misses PCL by $2 \mathrm{~mm}$. (B) Subluxation is present. The anterior aspect of spinous process of $C 2$ misses the $P C L>2 \mathrm{~mm}$. Finding is suggestive of a hangman's fracture of the neural arches of C2. (C) Pseudosubluxation is present. The anterior aspect of spinous process of $\mathrm{C} 2$ touches or lies within $2 \mathrm{~mm}$ of PCL. (Adapted from figure from Fesmire FM and Luten RC. ${ }^{16}$ ) 


\begin{tabular}{|c|c|c|c|c|}
\hline Author, date, country & Patient group & Study type & Results & Weaknesses \\
\hline $\begin{array}{l}\text { Viccelio et al, 2001, } \\
\text { USA (NEXUS) }\end{array}$ & $\begin{array}{l}3065 \text { patients aged } \\
<18 \text { years in } 21 \\
\text { centres undergoing } \\
\text { radiography for } \\
\text { blunt trauma. }\end{array}$ & $\begin{array}{l}\text { Prospective, observational } \\
\text { study of a decision } \\
\text { instrument of whether or } \\
\text { not to undertake radiography. }\end{array}$ & $\begin{array}{l}30 \text { spinal cord injuries. } \\
\text { Instrument sensitivity } 100 \% \\
\text { (Cl } 87.8 \text { to } 100.0 \% \text { ). }\end{array}$ & $\begin{array}{l}\text { Small number of injured } \\
\text { patients. }\end{array}$ \\
\hline \multirow[t]{2}{*}{$\begin{array}{l}\text { Lally et al, 1989, } \\
\text { USA }\end{array}$} & $\begin{array}{l}187 \text { children who had } \\
\text { c-spine radiographs: all } \\
\text { fractures over a } 20 \text { year } \\
\text { period plus all attendances } \\
\text { over a } 2.5 \text { year period }\end{array}$ & $\begin{array}{l}\text { Retrospective, blinded } \\
\text { review of radiographs } \\
\text { and review of notes. }\end{array}$ & $\begin{array}{l}16 \text { radiological abnormalities. } \\
\text { No injury below } C 4 \text { in under } 8 \text { s. }\end{array}$ & Small numbers. \\
\hline & & & & $\begin{array}{l}\text { Age of "child" not } \\
\text { defined. } \\
\text { Retrospective. }\end{array}$ \\
\hline \multirow[t]{2}{*}{$\begin{array}{l}\text { Rachesky et al, } \\
1987 \text {, USA }\end{array}$} & $\begin{array}{l}2133 \text { children }<18 \text { years } \\
\text { with c-spine radiographs } \\
\text { for "trauma related event" } \\
\text { over a seven year period. }\end{array}$ & $\begin{array}{l}\text { Retrospective notes and } \\
\text { radiological review. }\end{array}$ & $\begin{array}{l}25 \text { radiological abnormalities. } \\
\text { Combination of history of neck } \\
\text { pain and vehicular accident } \\
\text { with trauma would have } \\
\text { identified all fractures. }\end{array}$ & Retrospective \\
\hline & & & & $\begin{array}{l}\text { Not blinded. } \\
\text { All initially "normal" } \\
\text { radiographs not reviewed. }\end{array}$ \\
\hline \multirow[t]{3}{*}{$\begin{array}{l}\text { Jaffe et al, } 1987 \text {, } \\
\text { USA }\end{array}$} & $\begin{array}{l}206 \text { children } 16 \text { years } \\
\text { or less: all children with } \\
\text { c-spine radiographs over } \\
\text { one year period plus all } \\
\text { children with proven or } \\
\text { suspected c-spine injury } \\
\text { over a } 10 \text { year period. }\end{array}$ & $\begin{array}{l}\text { Retrospective review of } \\
\text { notes and radiographs }\end{array}$ & $\begin{array}{l}59 \text { c-spine injuries, } \\
1 \text { SCIWORA. }\end{array}$ & Retrospective. \\
\hline & & & $\begin{array}{l}\text { Some outcome data. } \\
\text { Eight variables identified } \\
\text { as criteria for undertaking } \\
\text { radiography. }\end{array}$ & $\begin{array}{l}\text { Not blinded. } \\
27 \text { patients excluded for } \\
\text { missing data. }\end{array}$ \\
\hline & & & & $\begin{array}{l}\text { Does not state how outcome } \\
\text { data were obtained, or } \\
\text { length of follow up. }\end{array}$ \\
\hline \multirow[t]{2}{*}{$\begin{array}{l}\text { Keiper et al, } \\
1998, \text { USA }\end{array}$} & $\begin{array}{l}52 \text { children with history } \\
\text { of c-spine trauma in } \\
\text { whom 3-view c-spine } p \\
\text { lain films and CT } \\
\text { demonstrated no fracture. }\end{array}$ & $\begin{array}{l}\text { Retrospective review of } \\
\text { MRIs, CTs and plain films } \\
\text { by three neuroradiologists. } \\
\text { Clinical follow up. }\end{array}$ & 16 positive MRIs. & Retrospective. \\
\hline & & & $\begin{array}{l}36 \text { patients with negative } \\
\text { MRIs were all followed up } \\
\text { with no neurological sequelae. }\end{array}$ & Not blinded. \\
\hline
\end{tabular}

\section{Discussion with UK experts}

\section{RESULTS}

A total of 241 papers were identified, and all their abstracts read. Altogether 71 possibly relevant papers were obtained and appraised. This proved to be a difficult task as there is no agreed reference ("gold") standard that identifies all c-spine injuries, and many papers do not include clinical follow up, which might get around this problem.

When Sackett's criteria ${ }^{28}$ are applied, the only valid study left for consideration was the NEXUS study, ${ }^{10}$ in which children are considered as part of a large, all age study. The analysis of the NEXUS paediatric subpopulation has been separately published. ${ }^{32}$ Four papers dealing specifically with radiology in children who have suffered trauma are also reviewed. ${ }^{11}{ }^{33-35}$ Table 2 describes their key findings and weaknesses.

\section{DISCUSSION}

Clinicians require safe and effective protocols for clearing paediatric c-spines. Despite the limited evidence available, some recommendations can be made. Patients can be considered in three groups, based on the adult classification, but with consideration to the paediatric differences:

\section{Alert asymptomatic patients with a normal physical examination}

In children, as with adults, attempts have been made to identify those who do not require radiography. ${ }^{10}{ }^{11} 3334$ Any protocol must have high sensitivity even at the expense of specificity to avoid the potentially serious and costly consequences of missing even a small number of truly injured c-spines.

The national emergency $\mathrm{x}$-radiography utilization study $(\text { NEXUS })^{10}$ evaluated a decision instrument that classified patients as having a low probability of injury if they met all of the following five criteria:

1. no midline cervical tenderness

2. no focal neurological deficit

3. normal alertness

4. no intoxication

5. no painful, distracting injury

This prospective, observational study of 34069 patients (aged less than 1 year to 101) identified all but 8 of the 818 patients who had cervical spine injury (sensitivity 99.0\%).

The NEXUS subset of patients aged $<18$ years have subsequently been reported..$^{32}$ There were 3065 patients aged 
$<18$ years, of which 905 were aged 8 years or younger. Among those aged $<18$ years there were 30 spinal cord injuries, but only four in the age group 8 years or younger. All of these four were upper c-spine injuries, whereas lower cspine injuries were more common when considering the entire paediatric group. There were no cases of SCIWORA. The authors, while recognising that the study "does not prove definitively that the NEXUS low-risk criteria can be applied to children with complete safety" (as numbers are insufficient for this), do endorse cautiously the use of this decision instrument in children also.

The literature dealing specifically with children ${ }^{11} 33$ is in broad agreement with this (see table 2 ). In young children, where clinical assessment is more difficult and communication problematical, clinicians should have a low threshold for requesting radiographs, while recognising the yield is likely to be low.

\section{Patients with cervical spine symptoms or signs}

These patients should be immobilised and resuscitated as appropriate. They should then undergo the three standard radiography positions: AP, lateral, and open mouth views. Open mouth views are impossible in young children, because of their lack of understanding and cooperation required in holding the mouth open, and some have recommended avoiding them in children $<9$ years old. ${ }^{27}$ If the C7-Tl junction cannot be visualised at the first attempt, $(57 \%$ in Lally's study), ${ }^{33}$ the shoulders may be depressed by pulling on the arms, or oblique projections, or swimmer's views may be taken. ${ }^{9}$ Repeated attempts at plain views should be avoided, and if C7/Tl still cannot be visualised, CT is advised. ${ }^{20} \mathrm{~A}$ lateral view alone (in children, as with adults) is inadequate. ${ }^{11}$ Normal alignment and uniformity in the interspinous distance at $\mathrm{C} 7 / \mathrm{Tl}$ on the AP chest film helps in eliminating problems at that level.

MRI is the investigation of choice when there is a neurological deficit, and for demonstration of ligamentous or soft tissue injuries, ${ }^{35}{ }^{36}$ but it is only suitable for stable patients. In children $<10$ years, the commonest c-spine injuries are ligamentous injuries without fracture ${ }^{29}$ some of which require surgical stabilisation.

\section{Patients with impaired consciousness}

These patients pose the greatest problem for the clinician, as a neurological examination is limited, and they are also at highest risk of having an injury. ${ }^{33}$ The aim when imaging these patients is to make a diagnosis, while preventing further avoidable damage to the neural structures.

Continued immobilisation without further investigation is one option. However, collars provide incomplete immobilisation, risk pressure sores (less with Philadelphia collars), increase nursing workload because of continued log rolling, and risk delayed diagnosis.

A strong case could be made for CT or MRI the c-spine of all unconscious paediatric patients. This is particularly true with the advent of helical/spiral CT, which is quicker and uses smaller doses of radiation than conventional CT. ${ }^{37}{ }^{38}$ CT with reconstruction is good for bony injuries, but can miss clinically significant soft tissue or ligamentous injuries. ${ }^{35}$ MRI is better for ligamentous and cord injuries, ${ }^{36}{ }^{39-41}$ and for prognosticating in SCIWORA. ${ }^{27}$ For this reason, if a child is likely to remain unconscious for a prolonged period (say more than 48 hours), an MRI scan is the best way to ensure there is no clinically significant injury, especially if plain radiographs are normal. ${ }^{41}$ In Keiper's series, ${ }^{35}$ no child with a normal MRI (36 of 52) developed delayed clinical or radiological evidence of instability or deformity. (In adults there is a larger study suggesting that a negative MRI can "clear" the c-spine). ${ }^{42}$
In the care of the comatose traumatised adult, there has been considerable discussion regarding the use of dynamic flexion-extension studies under image intensification. ${ }^{453-46}$ Clancy has previously summarised the pros and cons of dynamic fluoroscopy compared with MRI ${ }^{47}$ Dynamic fluoroscopy is a cheaper, "bedside" test, but with potential risk of injury to the brainstem or spinal cord from movement of the spine if there is unsuspected fracture or instability. MRI is more expensive and difficult to undertake for this patient group, but no false negatives have been reported for ligamentous instability. It also avoids the risks of dynamic fluoroscopy. In the paediatric age group there are insufficient data published for the use of dynamic fluoroscopy. ${ }^{36}$ In the small minority of children who remain comatose at 48 hours MRI must be regarded as the safest way to clear the c-spine.

\section{CONCLUSION}

Clearance of the paediatric c-spine is difficult but the principles are the same as for adults. Alert, asymptomatic children with no distracting injuries and normal clinical examination may be cleared clinically. In obtunded patients more detailed imaging is necessary. CT (for example, spiral CT post-resuscitation) provides the best imaging of bony injury, and MRI at 48 hours for those who remain obtunded would be an achievable goal (in the absence of evidence) for most large UK hospitals.

We strongly recommend to readers a comprehensive literature review Guidelines for Management of Acute Cervical Spinal Injuries, ${ }^{27}$ which deals with a broad range of issues, many relevant to the practice of emergency medicine. This was published after our paper was submitted. These two independent reviews have reached similar conclusions.

\section{ACKNOWLEDGEMENTS}

We are grateful to Professor H Carty, Professor of Paediatric Radiology at Alder Hey Hospital, Liverpool, for her helpful comments on the early drafts of this review.

\section{Contributors}

M Clancy initiated the review, and commented on drafts of the paper. S Slack performed the literature search, reviewed the relevant articles, and drafted the writing of the paper. Both authors will act as guarantors.

\section{Authors' affiliations}

S E Slack, Department of Accident and Emergency Medicine, North Hampshire Hospital, Basingstoke, UK

M J Clancy, Department of Accident and Emergency Medicine, Southampton General Hospital, Southampton, UK

Funding: none.

Conflicts of interests: none declared.

\section{REFERENCES}

1 Clancy MJ. Clearing the cervical spine of adult victims of trauma. J Accid Emerg Med 1999; 16:208-14.

2 Banit DM, Grau G, Fisher R. Evaluation of the acute cervical spine: a management algorithm. J Trauma 2000;49:450-6.

3 Brohi K, Wilson-Macdonald J. Evaluation of unstable cervical spine injury: a 6-year experience. J Trauma 2000;49:76-80.

4 Lockley AS, Handley R, Willett K. 'Clearance' of cervical spine injury in the obtunded patient. Injury 1998;29:493-7.

5 Brooks RA, Willett KM. Evaluation of the Oxford protocol for total spinal clearance in the unconscious trauma patient. J Trauma 2001;50:862-7.

6 Wales LR, Knopp RK, Morishima MS. Recommendations for evaluation of the acutely injured cervical spine: a clinical radiologic algorithm. Ann Emerg Med 1980;9:422-8.

7 Ruge JR, Sinson GP, McLone DG, et al. Pediatric spinal injury: the very young. J Neurosurg 1988;68:25-30.

8 Kewalramini LS, Kraus JF, Sterling HM. Acute spinal-cord lesions in a paediatric population: epidemiological and clinical features. Paraplegia 1980;18:206-19. 
9 Carty H, Shaw D, Brunelle F, et al. Imaging children. Edinburgh: Churchill Livingstone, 1994:1167-75.

10 Hoffman JR, Mower WR, Wolfson AB, et al. Validity of a set of clinical criteria to rule out injury to the cervical spine in patients with blunt trauma. NEngl J Med 2000;343:94-9.

11 Jaffe DM, Binns H, Radkowski MA, et al. Developing a clinical algorithm for early management of cervical spine injury in child trauma victims. Ann Emerg Med 1987; 16:270-6.

12 Ehara S, El-Khoury G, Sato Y. Cervical spine injury in children: radiologic manifestations. AJR Am J Roentgenol 1988;151:1175-8.

13 Henrys $\mathbf{P}$, Lyne ED, Lifton C, et al. Clinical review of cervical spine injuries in children. Clinical Orthop 1976;129:172-6.

14 Hill SA, Miller CA, Kosnik EJ, et al. Pediatric neck injuries. J Neurosurg 1984;60:700-6.

15 Kriss VM, Kriss TC. Imaging of the cervical spine in infants. Pediatr Emerg Care 1996;13:44-9.

16 Fesmire FM, Luten RC. Evaluation of the pediatric cervical spine. In: The clinical practice of emergency medicine. Philadelphia: Lippincott-Raven, 1996: 1197-201

17 Eleraky MA, Theodore N, Adams M, et al. Pediatric cervical spine injuries: report of 102 cases and review of literature. J Neurosurg: (Spine 1) 2000;92:12-17.

18 Givens TG, Polley KA, Smith GF, et al. Pediatric cervical spine injury: a three year experience. J Trauma 1996:41:310-14.

19 Alker GJ, Young S, Leslie EV, et al. Postmortem radiology of head and neck injuries in fatal traffic accidents. Neuroradiology 1975;114:611-17.

20 American College of Surgeons. Committee on Trauma. Advanced life support course for physicians. Chicago: American College of Surgeons, 1997.

21 Cattell HS, Filtzer DL. Pseudosubluxation and other normal variations in the cervical spine in children. J Bone Joint Surg (Am) 1965;47-A:1295-305.

22 Shaw M, Burnett $H$, Wilson $A$, et al. Pseudosubluxation of $C 2$ on $C 3$ in polytraumatized children-prevalence and significance. Clin Radiol 1999:54:377-80.

23 Advanced Paediatric Life Support Working Group. Advanced paediatric life support. 2nd edn. London: BMJ Books, 1997:174.

24 Anderson JM, Schutt AH. Spinal injury in children. Mayo Clin Proc 1980;55:499-504.

25 Dickman CA, Zabramski JM, Rekate HL, et al. Spinal cord injuries in children without radiographic abnormalities. Western J Med 1993;158:67-8.

26 Pang D, Wilberger JE. Spinal cord injury without radiographic abnormalities in children J Neurosurg 1982;57:114-29.

27 American Association of Neurological Surgeons and the Congress of Neurological Surgeons. Guidelines for management of acute cervical spinal injuries. Neurosurgery 2002;50:suppl 3.

28 Sackett DL, Richardson WS, Rosenberg W, et al. Evidence based medicine. How to practice and teach EBM. London: Churchill Livingstone, 1997:81-4.
29 Rosen P, ed. Emergency medicine. Concepts and clinical practice. 4th edn. St Louis: Mosby, 1998.

30 Silverman FN, Kuhn JP. Caffey's pediatric x-ray diagnosis: an integrated imaging approach, 9th edn. St Louis: Mosby, 1993:120-9, 138-43.

31 Keats TE, Anderson MW. Atlas of normal Roentgen variants that may simulate disease. 7th edn. St Lovis: Mosby, 2001.

32 Viccellio $P$, Simon $H$, Pressman $B D$, et al. A prospective multicenter study of cervical spine injury in children. Pediatrics 2001;108:e20.

33 Lally KP, Senac M, Hardin WD, et al. Utility of the cervical spine radiograph in pediatric trauma. Am J Surgery 1989;158:540-2.

34 Rachesky I, Boyce WT, Duncan B, et al. Clinical prediction of cervical spine injuries in children. Am J Dis Child 1987;141:199-201.

35 Keiper MD, Zimmerman RA, Bilaniuk LT. MRI in the assessment of the supportive soft tissues of the cervical spine in acute trauma in children. Neuroradiology 1998;40:359-63.

36 Scarrow AM, Levy El, Resnick DK, et al. Cervical spine evaluation in obtunded or comatose pediatric trauma patients: s pilot study. Pediatr Neurosurg 1999:4:169-75.

37 Coleman LT, Zimmerman RA. Pediatric craniospinal spiral CT: current applications and future potential. Semin Ultrasound CT MR 1994;15:148-55.

38 Blackmore CC, Mann FA, Wilson AJ. Helical CT in the primary trauma evaluation of the cervical spine: an evidence based approach. Skeltal Radiol 2000;29:632-9.

39 Silberstein $M$, Tress BM, Hennessy O. A comparison between MRI and CT in acute spinal trauma. Australas Radiol 1992;36:192-7.

40 Frank JB, Lim CK, Flynn JM, et al. The efficacy of magnetic resonance imaging in pediatric cervical spine clearance. Spine 2002;27:1176-9.

41 Dormans JP. Evaluation of children with suspected cervical spine injury. J Bone Joint Surg Am 2002;84A: 124-34.

42 Benzel EC, Hart BL, Ball PA, et al. Magnetic resonance imaging for the evaluation of patients with occult cervical spine injury. J Neurosurg 1996;85:824-9.

43 Sees DW, Cruz LRR, Flaherty SF, et al. The use of bedside fluoroscopy to evaluate the cervical spine in obtunded trauma patients. J Trauma 1998;45:768-71

44 Davis JW, Parks SN, Detlefs CL, et al. Clearing the cervical spine in obtunded patients: the use of dynamic fluoroscopy. J Trauma 1995;39:435-8.

45 Ajani AE, Cooper DJ, Scheinkestel CD, et al. Optimal assessment of cervical spine trauma in critically ill patients: a prospective evaluation. Anaesth Intensive Care 1998;26:487-91.

46 Pollack CV, Hendey GW, Martin DR, et al. Use of flexion-extension radiographs of the cervical spine in blunt trauma. Ann Emerg Med 2001;38:8-11.

47 Clancy M. Clearing the cervical spine in the unconscious trauma patient [Letter]. Emerg Med J 2001;18:233.

48 Stiell IG Wells GA, Vandemheen KL, et al. The Canadian c-spine rule for radiography in alert stable trauma patients. JAMA 2001;286:1841-8. 